\title{
46,XX testicular disorder of sex development
}

INSERM

\section{Source}

INSERM. (1999). Orphanet: an online rare disease and orphan drug data base. 46,XX testicular disorder of sex development. ORPHA:393

$46, \mathrm{XX}$ testicular disorder of sex development $(46, \mathrm{XX}$ testicular $\mathrm{DSD})$ is characterized by male external genitalia, ranging from normal to ambiguous with associated testosterone deficiency. 